\title{
Understanding the Meaning of Multicultural Collaboration in a Public-School EFL Class
}

\author{
Allyson Donoso \\ Katherin Ortega \\ Universidad Central de Chile \\ Chile \\ Patricio A. Pino Castillo \\ Facultad de Educación, Universidad Santo Tomás \\ Chile
}

\begin{abstract}
This phenomenological study sought to understand the meaning of multicultural collaboration in a Chilean English as a Foreign Language class purposefully selected because of its high percentage of students from different cultural backgrounds. Through participant observation and in-depth interviews, the essence of the phenomenon was identified. Findings revealed that the students' and the teacher's positive attitudes towards multiculturalism, along with their respect and acceptance for diversity, propitiated a healthy and safe learning environment that made multicultural collaboration possible. Future studies should explore how these conditions may be replicated in other multicultural educational scenarios.
\end{abstract}

KEYWORDS: Multicultural classroom, adolescents, English, peace education, immigrant students

\author{
Literature Review \\ Method \\ Results \\ Discussion \\ References \\ Author Contact
}

The increasing migration into Chile has been a controversial topic in the country, and according to the latest immigration report provided by the Chilean Ministry of Domestic Affairs (Departamento de Extranjería y Migración del Ministerio del Interior y Seguridad Pública, 2019), there has been a sharp increase in visas issued to foreigners, from 166,464 in 2015 to 443,041 in 2018. These new Chilean citizens, $62 \%$ of whom reside in the capital, come mainly from Peru, Colombia, Venezuela, Bolivia, and Haiti. This has had an impact on the Chilean educational system; according to the Ministry of Education, the number of migrant students has risen from 30,625 (making up $0.9 \%$ of students) in 2015 , to 113,585 (making up 3.2\% of students) in 2018. These students mainly attend public schools 
(57\%) in the Metropolitan Region (59.3\%) in which the capital is located (Ministerio de Educación [MINEDUC], 2018).

Many countries have dealt with the inclusion of migrants into different areas of society. In the case of education, the incorporation of these students into the system should provoke a shift to multicultural education which, according to Sleeter (1991), "attempts to redesign classrooms and schools to model an unoppressive, equal society which is also culturally diverse" (p. 11). However, migrants have historically been regarded with prejudice and judgment, as a study carried out by Cerón, Alvarado, and Poblete (2017) explains; the diversity that migrants represent is seen as an obstacle, as teachers have personal prejudice about migrant people. This in turn may engender concrete or symbolic acts of discrimination that affect the children's health and social relations in and out of school, and may also lead to physiological and psychological problems (Perreira, Kiang, \& Potochnick, 2013). At the other end of the spectrum, Allen, Jackson and Knight claim that "culturally relevant teachers recognize students' cultural knowledges, values, and ways of being as strengths, facilitating the development of culturally conscious identities" (2012, p. 3).

This integration into the classroom of students from different cultural backgrounds has received more attention in recent studies that have shown its benefits, such as the one carried out by Sánchez (2011), who asserted that this diversity more often entails an enrichment that educational institutions should take advantage of, especially for the practice of experiences related to Education for Peace (p. 128). According to Bernabé (2012), diversity, respect, and cultural dialogue are more often present and accepted in this type of classroom, which generates peaceful coexistence among the participants. Similarly, according to Hernández, Luna, and Cadena (2017), the culture of peace is a process of consolidating a new way of seeing, understanding, and living in the world, starting with the self and continuing with others, horizontally forming a network, promoting mutual exchange, and overcoming differences (p. 157). These values are important in the classroom and among the students. Finally, according to Zurbano (1998), education should develop attitudes and behaviors more compatible with justice, respect, tolerance, dialogue, and the non-violent resolution of conflicts ( $p$. 13).

This study set out to explore the peaceful coexistence of students and teacher in a vulnerable multicultural school in Santiago de Chile. Amidst the worrying levels of violence in underprivileged Chilean classrooms that led to the passing of a law, Ley Aula Segura, which makes it possible for students to be expelled when they have become a threat to other students and teachers (Albert, 2018), understanding how a school can avoid discrimination and violence through collaboration presents itself as a crucial aim for inquiry. Through a phenomenological design, this study was intended to understand the meaning of multicultural collaboration. 


\section{Literature Review}

The concept of multicultural education has been discussed for years. Its meaning has been changing but its essential aspects are maintained. In 1991, Sleeter stressed that multicultural classrooms should be the reflection of a diverse and inclusive society (1991, p. 11). In her view, there is a relationship between multicultural education and empowerment, and this approach could generate changes in the educational system. She postulated that, with this approach, minorities could be incorporated instead of leaving educational decisions to a group of people who do not represent everyone.

Decades later, Banks and McGee (2010) postulated that multicultural education emerged from the needs of minorities, propelling a change in the educational system whose main purpose became the conviction that all students, regardless of their race, cultural group, or language, could receive an equal education. In this approach, the experiences, interests, and opinions of the minorities are relevant in the classroom and for education. Banks and McGee (2010) emphasize the importance of teachers identifying these factors and incorporating them in their teaching practice.

There are different strategies, methodologies, and approaches for multicultural classrooms seeking to incorporate diversity. One of the most used strategies for this type of classroom stems from the outstanding scholarly work of Geneva Gay: culturally responsive teaching (CRT), which according to Vavrus (2008) is "a response to traditional curricular and instructional methods that have often been ineffective for students of color, immigrant children and students from lower socioeconomic families" (p. 49). Moreover, Vavrus (2008) explains that CRT means teachers learning about students' previous experiences and cultural background and then using this knowledge in the building of a caring and diverse classroom that also challenges students to success.

Another strategy used in multicultural classrooms is Intercultural Pedagogy, which according to Escalante, Fernández, and Gaete (2014) proposes a rational strategy for social and cultural integration of the ethnic minorities (p. 73). Furthermore, the authors explain that intercultural pedagogy is focused on the dialogue between the different cultures based on the recognition of diversity. Thus, this strategy is focused on the integration of the person into the educational system and into the new culture, while respecting their culture of origin.

An additional strategy is Dialogic Learning which, according to Imbernón (2000), is achieved through planned activities from an open and flexible perspective that addresses all aspects that affect the educational process. Following Paulo Freire's vision of critical pedagogy, the actors involved in this process participate in a relation of horizontality (p. 168). Imbernón emphasizes that constant dialogue and reflection are key factors for the application of this strategy, in an environment of mutual collaboration. 
Although each strategy mentioned above has components that make it different from the others, all three strive to incorporate the previous experiences and cultural background of the students into the classroom, making an inclusive environment where the classes are flexible and the dialogue is constantly present.

The use of inclusive and multicultural strategies not only helps teachers make learning more meaningful; it also contributes to peaceful coexistence. Peace is a key element in any society, and it is particularly relevant in education, considering its preponderant role in society. The 26th article of the Universal Declaration of Human Rights (1948) firmly states that education must encourage tolerance and friendship among cultures, boosting people's growth and strengthening respect for freedom.

Some authors have expressed their belief that peace education is a way of seeing and understanding life. Hernández, Luna, and Cadena (2017) state that the culture of peace is a process of consolidating a new way of seeing, understanding, and living in the world, starting with the self and continuing with others, horizontally forming a network, promoting mutual exchange and overcoming differences ( $p$. 157). Furthermore, the authors stress that peace education considers human problems as an opportunity to grow and promote new ways to solve such problems. Zurbano (1998) goes beyond this assertion and offers principles that a peace education should have, such as the cultivation of values, a respectful coexistence, and educating about tolerance, diversity, and resolution of problems.

These values, in turn, are conceived to promote collaborative learning, enriching the learning process. According to Johnson and Johnson (2014), collaboration occurs "when individuals cooperate, they work together to accomplish shared goals, and there is a mutual responsibility to work for one's own success" (p. 841). Earlier, in 1996, Dillembourgh and Baker had explained that "collaborative learning methods share the idea that students work together to learn and are responsible for their own learning and that of their classmates" (as cited in Collazos \& Mendoza, 2006, p. 62).

The Chilean government is aware of the important work that teachers do and how their preparation has an impact on their students. For this reason, the Ministry of Education created standards (which include attitudes, contents, and knowledge) that teachers must have when they begin to teach (MINEDUC, 2014). Standard Number 4 for an English teacher mentions that the teacher is in charge of helping students develop skills that give them the tools for communication ( $p$. 26). The skills mentioned in this standard are reading, listening, speaking, and writing, and emphasizing the relationship among them; the teacher must fully understand the importance of these and organize the class in a way so that students can practice the four skills in one class, maintaining the communicative purpose.

In agreement with the information above, Brown (2000) mentioned that "foreign language learning is viewed not just as a potentially predictable developmental process but also as the creation of meaning through interpersonal negotiation among learners" (p. 195). This emphasizes the importance of the 
communicative focus in the learning process, because in this interaction students apply a wide range of vocabulary and knowledge to participate in these activities. For this reason, teachers and schools design their planning with this communicative focus as Brown (2000) has expressed: "Communicative language teaching still stands as an appropriate term to capture many of the most recent trends in...teaching" (p. 195).

As we can see, diversity, peace education, and multicultural classrooms bring several benefits. Along this line, a study in Spain conducted by Aguadez, Buendía, Expósito, and Sánchez (2015) concluded that although multicultural coexistence is an important issue for the educational system, there are not enough resources allocated to education to make improvements; therefore, the different strategies and the curricular adaptations for this type of classroom are not appropriate for achieving inclusion. In Chile, the government knows about this reality, but the evidence has shown that teachers do not receive enough tools to integrate diversity in their classes. Nowadays, the only program that the government has is one called Bilingual Intercultural Education which is focused on recovering the indigenous cultures in the national territory, people who reside mainly in the north and south of the country and have for years been excluded from the cultural heritage taught in schools. However, this program does not include suggestions for inclusion nor adaptations for migrant students in the classroom, leaving a gap.

Considering the acknowledged gap in knowledge and the relevance of the phenomenon, the purpose of this descriptive phenomenological study was to understand multicultural collaboration in a multicultural English class at a public high school in Santiago de Chile. The research question that guided the study was the following: What is the meaning of multicultural collaboration for adolescents and teacher at a multicultural English class in a public high school in Santiago?

\section{Method}

According to Padilla-Díaz (2015), descriptive or hermeneutical phenomenology refers to the study of personal experience and requires a description or interpretation of the meanings of phenomena experienced by participants in an investigation (p. 103). This type of phenomenology is the closest to our research purposes, and it is consonant with an interpretive research paradigm. According to Cohen, Manion, and Morrison (2005), the interpretive researcher attempts to understand phenomena in the same way as an insider, getting directly involved in the activities related to it, in an effort to grasp the whole picture of the subjective reality.

This endeavor is also coherent with a qualitative approach, which, according to Hernández, Fernández, and Baptista (2014), is the collection of nonstandardized data for the perspectives and points of view of the participants (p. 8). As we wanted to know the participants' perspectives of and about their class, we achieved this through participant observation and ethnographic interviews with 
students and the teacher about their experiences in classes. "Qualitative research takes into account that viewpoints and practices in the field are different because of the different subjective perspectives and social backgrounds related to them" (p. 16), which is why we recorded field notes of the observations during classes and conducted interviews with participants in order to reflect these different subjective perspectives.

\section{Participants}

Our study took place in a high school class of 30 students located in the Metropolitan Region in Estación Central district. We purposefully chose this school because, according to Barrios-Valenzuela and Palou-Julián (2014), this is one of the districts that concentrates the largest number of immigrants. We selected the 9th grade, as this class had a higher percentage of migrant students, which was the phenomenon of our interest. Students were between 14 and 15 years old. The majority of the students came from Venezuela, Haití, Colombia. and Dominican Republic. Only six students (20\%) out of 30 were Chilean.

The teacher of English had studied English language teaching in Santiago and had never lived or travelled abroad. He had been working there for five years, and he reportedly enjoyed working there. He voluntarily and without any specific training on CRT or other multicultural strategies took students' experiences and interests into consideration for planning classes. During the classes he tried to speak English most of the time, but he also spoke Spanish, usually when he repeated the instructions. As there were bilingual students in the class, the teacher usually asked them for help in the activities, or to provide examples either in oral form or in written form for the whole class.

\section{Procedures}

Our participant observation and interviews were connected with four key areas of research: (a) teaching strategies for a multicultural classroom, defined as multicultural strategies that accept and integrate diversity in the classroom to accomplish the best academic performance for each student; (b) peace education, defined as an education that promotes and develops attitudes in students such as respect, tolerance, and justice for the creation of a safe classroom environment; (c) social development in adolescents, defined as a stage when teenagers leave their child identity and take a new identity which is more in accordance with their actual interests and ideas; and (d) the teacher of English, who was defined as a teacher that helps students develop and integrate the four language skills, namely reading, writing, listening, and speaking, in English for communicative purposes. All these categories were related with each other and are connected to the central phenomenon of our interest, which we sought to understand from the participants' perspectives and activities in the classroom. 
In line with the purposes of our phenomenological study, we made field notes for recording observations and interviews of the teacher and the students, in order to know the participants' perspectives. The teacher's informed voluntary participation was recorded in a letter of consent; the students' voluntary participation included both a letter of consent to parents and a simplified letter of consent for students.

Observation. In accordance with the constructivist perspective that guided our inquiry, the phenomenon was conceived as intersubjective (Guba \& Lincoln, 2005). Therefore, we used participant observations to delve into the school context, the relationship between students and the teacher, and how the teacher organized the class. According to Flick (2009), observations allow the researcher to get fully immersed in the participants' world, collecting rich data about activities and behavior around the phenomenon under study.

We made fieldnotes every week, in which we recorded the more remarkable situations and experiences that could help us understand the phenomenon. With this information we could get to know the classroom environment, the students' relationships, and the teacher's role without affecting their daily routines. Moreover, this data assisted in purposefully selecting the key informants for the individual interviews that we conducted later on.

Ethnographic interviews. We carried out ethnographic interviews with six students of different nationalities, who were selected due to their contribution to the collaborative environment, and with the teacher, since for our study it was important to know their opinions and impressions about how they signify this multicultural classroom. According to Cohen, Manion, and Morrison (2005), "interviews enable participants...to discuss their interpretations of the world in which they live, and to express how they regard situations from their own point of view" (p. 267).

We selected ethnographic interviews for the students and for the teacher because the focus was to gather the real ideas and opinions of the interviewees; therefore, it was necessary that they felt comfortable, secure, and free to express themselves. According to Flick (2009), for this kind of interview "the local and temporal framework is less clearly delimited than in other interview situations, where time and place are arranged exclusively for the interview. Here opportunities for an interview often arise spontaneously and surprisingly from regular field contacts" (p. 169).

The first students selected for the interviews were students from the bilingual group, because according to the information in the field notes they had high participation in the class and they always helped the teacher; therefore, we were interested in their opinions about this multicultural collaboration phenomenon. We continued with the interviews with other migrant students from different countries to learn whether all of them had similar opinions about the multicultural classroom. We wanted to understand if this kind of phenomenon had a relationship with the country of origin or if it was commonplace in any other 
country. Finally, we selected Chilean students to interview to learn their perceptions about this phenomenon.

In the case of the teacher's interview, we asked about his perceptions about the class, the students' behavior in the English class and in the rest of the subjects, and the methodology that he used for a multicultural classroom. This information helped us to understand if this phenomenon happened in any other subject or if was only in the English class.

For the students' interviews, we prepared similar questions for all of them, adapting some of them according to their nationalities. In the case of the migrants' interviews we asked how they felt in the course, how their experience studying in Chile had been, the things they had in common with Chilean students, and what their role in the course was. In the case of the Chilean students, we asked how they felt in the course, how their experience studying with migrant students had been, the things they had in common with migrant students, and what their role was in the course.

In order to ensure trustworthiness, we used data triangulation between the researchers' observations. Dependability was ensured by conducting a dependability audit with the help of an external advisor at the Faculty of Education, and also by theoretical sampling of data; confirmability was ensured by confirmability audit; and, finally, transferability was ensured by a thorough description of the context so that other researchers could judge whether the teacher's work in this school can be applied to other classes.

\section{Results}

Results were obtained from the analysis of fieldnotes and interviews. They will be presented in the steps suggested by Creswell (2013) for phenomenological studies: (a) textual description, in which researchers look for significant units that serve as the main themes for coding and categorizing in order to understand what people are saying about the phenomenon; (b) structural description, in which researchers analyze the ways in which people express their opinions and views, in order to understand how people are saying what they are saying; and (c) the essence of the phenomenon, which constitutes the findings.

\section{Textual Description}

We identified four main categories in the data. Following, we will present our inferences for each category, after triangulation between observation and interviews.

Teaching strategies for a multicultural classroom. During the observations and interviews, we found that the strategies used by the educational 
community for achieving discipline and responsibility were usually offering prizes or mentioning the students' parents. The overall development of the class was covered by the use of strategies that gave all students confidence. There were many nationalities in the class, so the classes focused on connecting new learning to students' previous experiences, for example, using slang from different countries: "Some foreign students asked to the teacher about the meaning of the word 'pitillo', which means something inappropriate in their dialect" (from fieldnotes April 18). Students were seen to behave comfortably, free to show the typical behavior from their cultures, and the teacher used that information to teach. In addition, the teacher benefitted from the bilingual students, especially Venezuelans, for improving the collaborative work among all students regardless of their nationality.

Peace education. During the observations and interviews, we found that the coexistence in the class demonstrated values such as acceptance, respect, fellowship, and collaboration among the students and the teacher. The class dealt with problems by giving solutions and discussing with respect and tolerance. The teacher and the students made the classroom environment more comfortable and enjoyable for all the people in the class. In general, they seemed to agree with the development of the class, where they tended to have respect for the others and show concern for all. The differences between the cultures in the classroom were beneficial for giving some extra information about dialects that sparked the students' motivation.

Social development in adolescence. In observations and interviews, it became clear that most students were used to sharing their interests with people from other cultures. A few students felt some discomfort because of the differences between Chilean and foreign students; most of the Chilean students were quiet and shy, and migrant students tended to be extroverted and noisier. Also, the number of foreign students surpassed the number of Chilean ones in the class, which was perceived by some Chilean students as discomforting: "nos sentimos totalmente extranjeros y sentimos que no encajamos entre ellos porque ellos ... pueden socializar con todos y nosotros somos como más calladitos" (We feel foreign and we feel we don't fit because they...can socialize with everybody and we are rather quiet). However, all students could demonstrate their own interests through the decoration of the classroom, the topic of the activities in classes, and during the jean days of the school, when they could go without the school uniform. Sometimes, students had some problems regarding the disorganization. A few of them showed demotivation with the school in general, not with the class. During classes, the students showed productivity, especially when there was some problem for resolving among all the students and the teacher, so they were free to give their opinions.

Teacher of English. The observations and interviews showed that the teacher of English appeared to be comfortable with his job. He showed closeness, having friendly conversations with students during the class. He demonstrated tolerance, for example, when asking students to speak more slowly for their classmates, and confidence in the students, constantly challenging them through 
active and collaborative participation in the class. This helped him create a comfortable environment in the class and helped him do his job. As he said to the students during one class, he teaches through skills instead of content, mainly by using the communicative approach during classes. He gave students instances to talk about their interests and allowed time for resolving problems with the students in an equal way for all of them. The teacher gave all the explanations of the class in English, and then in Spanish. He also tried to give the students input in English, by talking with the bilingual ones in front of the rest of the class.

\section{Structural Description}

A significant aspect of the situational context within which the phenomenon was experienced and signified is having an inclusive class, where the fears about possible discrimination do not happen. Foreign students constantly compared their country of origin with Chile in their answers, which demonstrated that they have a positive attitude towards living in this new country: "Siento que los estudiantes tienen mayor libertad de expresión, por lo menos en este colegio, más de la que había allá en (país de origen)" (I feel students have more freedom of speech, at least in this school, more than we had in [country of origin]).

Chilean students, who agreed with the positive environment, shared their opinion about the positive experience of being in a multicultural scenario: "La verdad me gusta [estudiar con personas de otras culturas] porque uno aprende a compartir con diferentes personas, aprender otras culturas también, es divertido aparte" (I like studying with people from other cultures, because this way I can learn to share with different people, learn about other cultures, and it is also fun). However, there were some who felt discomfort with the attitude of the foreign students, who were perceived as being too extroverted: "Igual es medio incómodo porque igual nosotros somos los que nos sentimos extranjeros porque igual somos como más callados que los otros" (it is rather uncomfortable, because we [Chileans] feel as foreigners, since we are shier than the others).

According to the answers and observations, even though Chilean students reported feeling foreign and rather uncomfortable by the extroverted attitude of students from other cultures, they seemed to be content with the teacher's work and with the multicultural environment in the classroom, where participants showed acceptance, collaborative relationships, freedom, and support. This provoked a safe and comfortable classroom.

\section{Presentation of Findings}

Combining our findings from the textual and structural description, we can infer that the meaning of multicultural collaboration was related to the positive attitude of students and teacher towards multiculturalism; all the participants 
worked for achieving coexistence in the class. The teacher's work was a cue for developing this positive and integrated environment. Even though there were some dislikes about the differences of attitudes in the class, in general it seemed to be a class that people felt comfortable and happy to be in.

The students and the teacher seemed to be comfortable with the environment of multiculturalism; the overall development of the class was characterized by students being content and having fun, and it demonstrated acceptance, freedom, support, and respect for each one of the participants. It was a class with a high number of immigrant students, but there were no glaring differences among the nationalities, only some differences related to the dialects. However, with the help of the teacher, even these differences were shared in an enjoyable and secure environment, explaining the meaning of some words. It seemed that students felt happy in the class. However, there was some discomfort among Chilean students because of the strong and extroverted personality of some migrant students. It seemed that the Chilean students always maintained a low participation in the class as if they did not want to be noticed.

Although it seemed that the subject was difficult, most students tried to do the tasks; they worked almost all the classes into their activities. In the classroom, there were a variety of levels of English, so students asked for help to the bilingual ones and the teacher; for that reason the overall development of the class was colored by the collaborative work among the participants. This collaboration between them contributed in making a good atmosphere in the class.

Considering the similarities rather than differences among students seems to be a key aspect of an effective multicultural learning environment. The teacher's work was important because he demonstrated that he considered the students' interests and feelings when giving his classes. The teacher was aware of the reality of students and the difficult period that they could go through, facing a change like migration. For that reason, he empowered the values mentioned before; he had a close relationship with the students, which benefitted the classroom environment. It seemed that the students considered the teacher as part of the class, instead of a distant authority. For that reason, we believe that the teacher had a central role in this environment of peace education: he emphasized collaboration among students and himself with empathy and making an instance for knowing each other out of the differences. The teacher made meaningful work for all of his students, demonstrating through his actions in the class that he loved teaching and wanted to teach students to value diversity, and the students perceived this.

The meaning of multicultural collaboration in the classroom is that the students can take the opportunity to be in a peaceful and diverse environment, one in which all of them could learn more about each other's cultures. The teacher's role in this environment is crucial, teaching students to value diversity, continuously showing them that they are all the same and that diversity is an instance for learning about and valuing other cultures. 


\section{Discussion}

As was substantiated in the participant observation and interviews, even though the teacher made no explicit reference to multicultural methods, the strategies employed exhibited elements from CRT (Vavrus, 2008), when he used his knowledge of the students' culture to make them feel included. His way of actively engaging students in the activities and making them participate can also relate to dialogic learning (Imbernón, 2000), establishing a horizontal relationship and constantly using dialogue and reflection. His was a class whose main characteristic was its peaceful environment. That environment was a result of the teacher's way of teaching; he was responsible, and he devoted time and energy to knowing his students. Through teaching English communicatively and collaboratively, he showed his trust in his students, and this trust was reciprocal.

This research demonstrates that for teaching in a multicultural environment it is important to consider the similarities instead of the differences and to take advantage of them. For example, in this case English Language was a common topic that all the participants shared. The teacher's work was important because he demonstrated that he considered the students' interests and feelings when giving his classes. We discovered that the teacher had a central role in this environment of peace education; he emphasized the collaboration among all the people who were present in the classroom. Therefore, the students had the opportunity to be in a peaceful and diverse environment, in which all of them could learn more about other cultures and be tolerant.

Our findings show the importance of dedicating more time to know students and teaching values, such as tolerance and respect, through communication. Our findings contradict those of Cerón, Alvarado, and Poblete (2017), as we found no prejudice toward migrant students in the teacher; instead, the diversity they represented was seen as a benefit and not an obstacle. Our findings also present a different point of view from that of Allen, Jackson, and Knight (2012), as students' racial background was an issue that the teacher used in order to create an environment in which differences were embraced, students' heritage and histories were considered, and their similarities were used in favor of collaboration. On the other hand, our results confirm the findings of Pimenova and Yarmakeev (2014), as capitalizing on the students' similarities rather than differences had a positive impact on the group dynamics. As teachers, it is important to dedicate more time to knowing more about the students' reality and using that information to encourage meaningful learning. Also, we consider that it is important for the government to give efficient tools for teachers related to the multicultural environment in a classroom. This teacher could on his own develop the necessary empathy and awareness to act as a mediator and facilitator of a collaborative environment in which all cultures are accepted and made visible, which is something that all children deserve to have. We were lucky to observe this happening naturally in a classroom, but it is the government's responsibility to 
guarantee that this is the rule and not the exception. Our society is changing, with migration increasing every day, and education must be prepared for receive students from other countries. Including Chilean and immigrant students equally by considering and valuing the feelings of both is key for improving the learning process in schools.

Future research should attempt to confirm whether the peaceful environment is richer in the world language subject, which lends itself to discussing various cultural topics. Additionally, there should also be research into what happens in a multicultural environment in private schools; it would be interesting to discover if with more funding, as is often found in private schools, the multicultural environment of a private school would change similarly.

\section{References}

Aguadez, E., Buendía, L., Expósito, J., \& Sánchez, C., (2015). Análisis de la convivencia escolar en las aulas multiculturales de Educación Secundaria [Analysis of school coexistence in multicultural secondary school classrooms]. Revista de Investigación Educativa, 33(2), 303-319.

Albert, C. (2018, November 6). Aula Segura: la dura violencia escolar de la que no se habla ["Safe Classroom": The harsh school violence people are not discussing]. Retrieved from https://ciperchile.cl/2018/11/06/aula-segura-ladura-violencia-escolar-de-la-que-no-se-habla/

Allen, K. M., Jackson, I., \& Knight, M. G. (2012). Complicating culturally relevant pedagogy: Unpacking African immigrants' cultural identities. International Journal of Multicultural Education, 14(2), 1-28.

Banks, J., \& McGee, C., (2010). Multicultural education: Issues and perspectives (7th ed.). Washington, D.C.: Wiley.

Barrios-Valenzuela, L., \& Palou-Julián, B. (2014). Intercultural education in Chile: Integrating foreign students into the school system. Educación $y$ Educadores, 17(3), 405-426.

Bernabé, M. (2012). Pluriculturalidad, multiculturalidad e interculturalidad, conocimientos necesarios para la labor docente [Pluriculturalism, multiculturalism and interculturalism, necessary knowledge for the teaching exercise]. Revista Educativa Hekademos, 11(5), 67-76.

Brown, H. (2000). Principles of language learning and teaching (5th ed.). San Francisco, CA: Pearson.

Cerón, L., Alvarado, M., \& Poblete, R., (2017). Percepciones docentes en torno a la presencia de niños y niñas migrantes en escuelas de Santiago: retos y desafíos para la inclusión [Teachers' perceptions on the presence of migrant children in schools in Santiago: Challenges for inclusion]. Revista Latinoamericana de Educación Inclusiva, 11(2), 233-246. 
Cohen, L., Manion, L., \& Morrison, K. (2005). Research methods in education (5th ed.). London: RoutledgeFalmer.

Collazos, C., \& Mendoza, J. (2006). Cómo aprovechar el "aprendizaje colaborativo" en el aula [How to make the most of collaborative learning in the classroom]. Educación y Educadores, 9(2), 61-76.

Creswell, J. W. (2013). Qualitative inquiry \& research design: Choosing among five approaches. Los Angeles, CA: Sage.

Departamento de Extranjería y Migración del Ministerio del Interior y Seguridad Pública (2019). Estadísticas migratorias [Migratory statistics]. Retrieved from: https://www.extranjeria.gob.cl/estadisticas-migratorias/

Escalante, C., Fernández, D., \& Gaete, M. (2014). Práctica docente en contextos multiculturales: Lecciones para la formación en competencias docentes interculturales [Teaching practice in multicultural contexts: Lessons for education in intercultural teaching competences]. Revista Electrónica Educare, 18(2), 71-93.

Flick, U. (2009). An introduction to qualitative research (4th ed.). London: Sage.

Guba, E. G., \& Lincoln, Y. S. (2005). Paradigmatic controversies, contradictions, and emerging confluences. In N. K. Denzin \& Y. S. Lincoln (Eds.), The Sage handbook of qualitative research (3rd ed., pp. 191-215). Thousand Oaks, CA: Sage.

Hernández, I., Luna, J., \& Cadena, M. (2017). Cultura de paz: una construcción desde la educación [Peace culture: A construction from education]. Revista Historia de la Educación Latinoamericana, 19(28), 149-172.

Hernández, R., Fernández, C. \& Baptista, P. (2014). Metodología de la investigación [Research methods] (6th ed.). México, D. F.: McGraw-Hill.

Imbernón, F. (2000). Escuela y multiculturalidad [School and multiculturalism]. Revista Pensamiento Educativo, 26(1), 153-171.

Johnson, D., \& Johnson, R. (2014). Cooperative learning in 21st century. Anales de Psicología, 30(3), 841-851.

Ministerio de Educación. (2018). Mapa del estudiantado extranjero en el sistema escolar chileno [A map of foreign students in the Chilean school system]. Retrieved from: https://www.mineduc.cl/wp-content/uploads/sites/19/2018 /05/MAPA_ESTUDIANTES_EXTRANJEROS_SISTEMA_ESCOLAR_CHI LENO_2015_2017.pdf

Padilla-Díaz, M. (2015). Phenomenology in educational qualitative research: Philosophy as science or philosophical science. International Journal of Educational Excellence, 1(2), 101-110.

Perreira, K. M., Kiang, L., \& Potochnick, S. (2013). Ethnic discrimination: Identifying and intervening in its effects on the education of immigrant children. In E. L. Grigorenko (Ed.), U.S. Immigration and education: Cultural 
and policy issues across the lifespan (pp. 137-162). New York, NY: Springer.

Pimenova, T., \& Yarmakeev, I. (2014). The formation of students' national selfawareness in EFL class. English Language Teaching, 7(12), 26-35.

Sánchez, S. (2011). Hacia la interculturalidad desde la cultura de paz. Una perspectiva educativa [Towards interculturalism through peace culture: An educational perspective]. Revista de Educación de Humanidades, 1, 117136.

Sleeter, C. (1991). Empowerment through multicultural education. New York, NY: State University of New York Press.

United Nations (1948). Universal declaration of human rights. Retrieved from https://www.ohchr.org/EN/UDHR/Documents/UDHR_Translations/eng.pdf

Vavrus, M. (2008). Culturally responsive teaching. In T. L. Good (Ed.), 21st century education: A reference handbook (Vol. 2, pp. 519-527). Thousand Oaks, CA: Sage.

Zurbano, J. L. (1998). Bases de una educación para la paz y la convivencia [Foundations of education for peace and coexistence]. Pamplona, Spain: Fondo de Publicaciones del Gobierno de Navarra.

\section{Author Contact}

Allyson Donoso, allysondonosog@gmail.com

Katherin Ortega, katherin.ortegab@gmail.com

Universidad Central de Chile, Toesca 1783, Santiago, Región Metropolitana,

Chile

Patricio Pino, patriciopinoca@santotomas.cl

Escuela de Educación Universidad Santo Tomás, Ejército 146, Santiago, Chile. 